\title{
Motieven voor de uitgifte van warrant-leningen
}

Dr. C.H. Veld

\section{Inleiding}

In de laatste twintig jaar is de aandelenwarrant in toenemende mate populair geworden als beleggings- en als financieringsinstrument. In mijn proefschrift (Veld, 1992a) wordt een uitgebreid overzicht gegeven van de literatuur op dit gebied. Voorts wordt verslag gedaan van een empirisch onderzoek naar Nederlandse warrants. In een ander artikel (Veld, 1992b) zijn de belangrijkste resultaten van het onderzoek naar het gebruik van de aandelenwarrant als beleggingsinstrument besproken. In dit artikel zal worden ingegaan op het gebruik van de aandelenwarrant als financieringsinstrument. Als zodanig vormt dit artikel een weergave van een belangrijk deel van mijn proefschrift

In paragraaf 2 van dit artikel worden karakteristieken van aandelenwarrants geanalyseerd. In paragraaf 3 wordt een theoretische analyse gepresenteerd van het gebruik van aandelenwarrants als financieringsinstrumenten, gevolgd door paragraaf 4 waarin de resultaten worden gepresenteerd van een enquête onder emittenten van leningen in combinatie met aandelenwarrants. Het artikel wordt afgesloten met paragraaf 5 waarin de belangrijkste conclusies uit de studie worden weergegeven alsmede enkele aandachtspunten voor toekomstig onderzoek.

\section{Karakteristieken van aandelenwarrants}

In het proefschrift is een analyse gemaakt van de 'aandelen call-warrant in een enge zin' als beleggings- en als financieringsinstrument. Teneinde call-warrants te kunnen onderscheiden van 'call-opties in een enge zin', zijn call-warrants gedefinieerd als opties die het recht geven op de koop van onderliggende waarden, die bij uitoefening passiva wor- den voor de uitgevende onderneming; 'call-opties in een enge zin' zijn gedefinieerd als rechten om onderliggende waarden te kopen die bestaande activa zijn voor de optie-uitgevende instelling c.q. persoon. De resulterende definitie van een 'aandelen call-warrant' is: 'het recht om nieuw te emitteren aandelen te kopen van de uitgevende onderneming'. Deze definitie omvat eveneens claimrechten en conversierechten. ${ }^{2}$ Claimrechten zijn gedefinieerd als: 'aandelen call-warrants verstrekt door de onderneming aan haar aandeelhouders met een oorspronkelijke looptijd van maximaal vier weken'. Conversierechten zijn gedefinieerd als: 'aandelen call-warrants die een uitoefenprijs hebben, welke alleen kan worden voldaan door inlevering van de bijbehorende obligatie'. Aandelen call-warrants die niet voldoen aan hetzij het criterium voor claimrechten, hetzij het criterium voor conversierechten, zijn gedefinieerd als 'aandelen call-warrants in een enge zin'. Deze 'aandelen call-warrants in een enge zin', in het vervolg aan te duiden als 'warrants', vormen het centrale onderzoeksthema in de studie.

Warrants kennen verschillende ontstaanswijzen. Ze kunnen het resultaat zijn van een 'pure' financieringstransactie, bijvoorbeeld in een emissie in combinatie met obligaties of aandelen. Het is ook mogelijk dat warrants bijvoorbeeld worden gebruikt als een vorm van personeelsbeloning of dividendbetaling. ${ }^{3}$

In de dissertatie is gekeken naar de ontstaanswijzen van warrants, uitgegeven door Nederlandse ondernemingen ${ }^{4}$, waarbij sprake was van notering op de Amsterdamse Effectenbeurs van zowel de warrants als de onderliggende aandelen. In tabel 1 (p. 531) ziet men dat van 1 januari 1976 tot en met

Dr. Chris Veld is verbonden aan de sectie Ondernemingsfinanciering van de Katholieke Universiteit Brabant. 
Tabel 1: Warrant-emissies in Nederland, door Nederlandse ondernemingen, van 1 januari 1976 tot 31 december 1991

\begin{tabular}{|c|c|c|}
\hline & $\begin{array}{l}\text { Aantal } \\
\text { emissies }\end{array}$ & $\begin{array}{l}\text { Aantal } \\
\text { verschillende } \\
\text { warrants }\end{array}$ \\
\hline In combinatie met obligaties & 21 & 27 \\
\hline $\begin{array}{l}\text { In combinatie met: } \\
\text { - gewone aandelen } \\
\text { - preferente aandelen }\end{array}$ & $\begin{array}{l}9 \\
1\end{array}$ & $\begin{array}{l}9 \\
1\end{array}$ \\
\hline Uitgifte tegen contanten & 6 & 6 \\
\hline $\begin{array}{l}\text { Als (gedeeltelijke) betaling } \\
\text { bij een fusie of overname }\end{array}$ & 3 & 3 \\
\hline Als dividend-betaling ${ }^{6}$ & 3 & 3 \\
\hline Totaal aantal & 43 & 49 \\
\hline
\end{tabular}

31 december 1991 in totaal 43 warrant emissies hebben plaatsgevonden. ${ }^{5}$

Aangezien zes ondernemingen twee verschillende warrants tegelijkertijd hebben geëmitteerd (aangeduid als warrants $A$ en $B$ ), zijn in totaal 49 verschillende warrants uitgegeven. Opvallend is dat de emissie van warrants in combinatie met obligaties de meest gebruikte emissie-vorm was. Deze emissies vormen $49 \%$ van het totale aantal emissies en zelfs $55 \%$ van het totale aantal verschillende warrants. Dit is ook de reden dat in de volgende paragraaf aandacht zal worden besteed aan emissies van obligaties in combinatie met warrants, in het vervolg aan te duiden als warrant-leningen.

\section{Motieven voor de uitgifte van warrant- leningen: theorie}

In de financieringsliteratuur worden motieven voor het gebruik van warrant-leningen meestal afgeleid van motieven voor het gebruik van converteerbare obligatieleningen; dit vanwege de grote gelijkenis tussen deze financieringsinstrumenten. De discussie wordt daarom geopend met motieven voor het gebruik van converteerbare obligatieleningen, die ook toepasbaar zijn op warrant-leningen. De in deze paragraaf genoemde motieven voor warrant-leningen gelden dan, tenzij anders vermeld, ook voor con- verteerbare obligatieleningen. Veld en Grazell (1991) onderscheiden traditionele motieven en moderne motieven. Volgens de traditionele motieven zijn warrant-leningen: ${ }^{7}$

1 een uitgestelde aandelenemissie tegen een gunstige prijs;

2 een goedkope vorm van (vreemd) vermogen.

Brennan en Schwartz (1988), Copeland en Weston (1988, p. 476) en Veld en Grazell (1991) hebben aangetoond dat, vanuit een doelstelling van marktwaardemaximalisatie, deze motieven als irrationeel kunnen worden beschouwd. Kort samengevat komt de argumentatie van deze auteurs op het volgende neer.

Een emissie van warrants in combinatie met obligaties (warrant-obligaties) is geen uitgestelde aandelenemissie tegen een gunstige prijs, omdat de uitoefenprijs van de warrants niet mag worden vergeleken met de aandelenprijs bij uitgifte, maar moet worden vergeleken met de aandelenprijs op de afloopdatum van de warrants. Deze laatste kan ver boven de uitoefenprijs liggen, in welk geval de onderneming 'opportunity costs' maakt doordat aandelen tegen een te lage prijs worden uitgegeven. Een andere mogelijkheid is dat de aandelenprijs op de afloopdatum onder de uitoefenprijs ligt; in dat geval vindt géén aandelenemissie plaats.

Het 'goedkoop vreemd vermogen'-argument is gebaseerd op het feit dat door toevoeging van een warrant aan een obligatielening de interest op deze lening met enige procent-punten kan worden verlaagd. Allereerst dient opgemerkt te worden dat een warrant-lening niet uitsluitend vreemd vermogen genereert; het bedrag dat voor de warrant-obligaties wordt betaald bestaat uit een bedrag dat voor de obligaties wordt betaald en een bedrag dat voor de warrants wordt betaald. De kostenvoet van het obligatiegedeelte zal gelijk zijn aan de kostenvoet van een vergelijkbare obligatie die zonder warrants is geëmitteerd. Copeland en Weston (1988) en Veld en Grazell (1991) hebben aangetoond dat de kostenvoet van het warrant-gedeelte op een hoger niveau ligt dan de kostenvoet van zowel de obligaties als de aandelen. Dit is ook intuïtief aannemelijk te maken: een belegger zal een hoger (verwacht) rendement eisen naarmate zijn risico hoger is. Het risico van een warrant is vele malen groter dan het ri- 


\section{MAB}

sico van een obligatie, hetgeen een hoger geëist rendement voor de belegger tot gevolg heeft, en dus een hogere kostenvoet voor de onderneming. Het gewogen gemiddelde van de kostenvoeten zal dan ook op een hoger niveau liggen dan de kostenvoet van een gewone obligatie. Op grond hiervan kan dan ook worden geconstateerd dat een warrant-lening geen goedkope vorm van vermogen is.

In academische studies kunnen economisch rationele motieven worden gevonden. De meeste studies concentreren zich op één enkel motief voor de uitgifte van warrant-obligaties. In mijn proefschrift zijn deze studies geïntegreerd in één conceptueel raamwerk. Eveneens zijn enige nieuwe aspecten toegevoegd. Het conceptueel raamwerk is gebaseerd op het Modigliani/Miller (1958) theorema, waaruit kan worden afgeleid dat in een wereld van perfecte, efficiënte en complete financiële markten, een uitgifte van warrant-obligaties leidt tot een afruil tussen rendement en risico zonder creatie van additionele waarde. In het geval dat niet (geheel) is voldaan aan deze marktcondities, zijn motieven voor de uitgifte van warrant-obligaties gebaseerd op (markt) imperfecties, inefficiënties en incompleetheid.

Relevante motieven kunnen dan zijn:

1 de relatieve ongevoeligheid voor het risico van de uitgevende onderneming;

2 de mogelijkheid om agency-kosten te vermijden;

3 de mogelijkheid om liquiditeitsproblemen op te lossen;

4 lagere transactiekosten;

5 overwaardering van de onderliggende aandelen;

6 onderwaardering van de onderliggende aandelen.

Voorts worden enige motieven onderscheiden die specifiek zijn voor Nederland:

7 accounting voordelen;

8 (vermeende) fiscale voordelen;

9 de overwaardering van Nederlandse warrants.

Onderstaand zullen deze motieven verder worden uitgewerkt. $^{8}$

Ad. 1 Relatieve ongevoeligheid voor het risico van de onderneming.

Brennan en Schwartz (1988) stellen dat warrant-leningen een oplossing kunnen brengen indien de markt het risico van een onderneming te hoog inschat. In een dergelijk geval verlangt de markt een te hoge interestvergoeding op gewone obligaties. Indien een warrant-lening wordt uitgegeven speelt dit probleem nog steeds voor het obligatiegedeelte.

Aan de andere kant zal de markt bereid zijn om een (te) hoog bedrag te betalen voor het warrant-gedeelte, omdat de warrant meer waard is naarmate het risico hoger is. Op deze manier kan een warrantlening een oplossing brengen indien verschil van perceptie bestaat tussen het management van de onderneming en de markt over de hoogte van het risico.

Ad. 2 De mogelijkheid om agency-kosten te vermijden.

Het tweede motief hangt sterk samen met het eerste en is wederom gebaseerd op het feit dat de combinatie van een obligatie en een warrant relatief ongevoelig is voor het risico van de uitgevende onderneming. Jensen en Meckling (1976) stellen dat indien een onderneming een gewone obligatielening uitgeeft, de eigen vermogensverschaffers van deze onderneming de mogelijkheid hebben om direct na de obligatie-emissie de waarde van het eigen vermogen te vergroten ten koste van de obligatiehouders door risicovollere projecten te entameren. Aangezien het eigen vermogen kan worden beschouwd als een call-optie op de waarde van de onderneming $^{9}$ stijgt hierdoor de waarde van het eigen vermogen. Onder de veronderstelling dat de waarde van het totale vermogen constant blijt, daalt hierdoor de waarde van het vreemd vermogen..$^{10}$ Vreemd vermogensverschaffers zullen dit potentiële gevaar voorzien en zullen daarom aanvullende voorwaarden stellen, zoals bijvoorbeeld toezicht door een onafhankelijke commissaris. Deze voorwaarden brengen extra kosten met zich mee, zogenaamde agencykosten, die ten laste van de winst (dus de vergoeding voor de eigen vermogensverschaffers) komen. Deze kosten kunnen worden voorkomen door de uitgifte van een warrant-lening. In dat geval betekent een toeneming van het risico door het entameren van meer risicovolle projecten weliswaar dat de waarde van het obligatiegedeelte zal dalen, maar daartegenover staat dat de waarde van de warrant zal stijgen." 


\section{MAB}

Ad. 3 De mogelijkheid om liquiditeitsproblemen op te lossen.

Brealey en Myers (1991, p. 549) stellen dat warrantleningen liquiditeitsproblemen op kunnen lossen voor snel groeiende ondernemingen die worden geconfronteerd met hoge uitgaven voor, vaak laatrenderende, investeringsprojecten. Door het toevoegen van warrants aan een obligatielening wordt (uiteraard) de jaarlijks te betalen coupon interestvoet verlaagd. In ruil daarvoor verwerft de belegger een (verwachte) koerswinst op het moment dat het investeringsproject cash-flows genereert. De verlaagde couponvoet impliceert een verlaging van de cash-uitgaven aan het begin van het project.

\section{Ad. 4 Lagere transactiekosten.}

In geval van een warrant-lening wordt direct vreemd vermogen verkregen, waarna in de toekomst mogelijk eigen vermogen wordt verworven door uitoefening van de warrant-rechten. Dit brengt minder transactiekosten met zich mee dan een afzonderlijke emissie van obligaties nu, gevolgd door een toekomstige uitgifte van aandelen. Dit wordt ondersteund door resultaten van Mikkelson en Partch (1986). Zij constateren voor een steekproef van emissies door Amerikaanse ondernemingen dat de transactiekosten voor aandelen- en obligatieemissies, $6 \%$, respectievelijk $1,3 \%$ bedragen. Converteerbare obligatieleningen vergen slechts transactiekosten van $3,8 \%$.

\section{Ad. 5 Overwaardering van de onderliggende aan- delen.}

Indien de aandelen van een onderneming worden overgewaardeerd door de markt ${ }^{12}$, kan het aantrekkelijk zijn voor de onderneming om aandelen te emitteren. Echter, aangezien warrants 'levered securities' zijn zullen deze nog meer worden overgewaardeerd dan de onderliggende aandelen zelf. ${ }^{13}$ In een dergelijk geval zal het aantrekkelijk zijn om warrants tegen contanten uit te geven. Indien de onderneming, om welke reden dan ook, geen aandelen of warrants tegen contanten wenst te emitteren, kan een emissie van warrants in combinatie met obligaties een alternatief zijn.

Ad. 6 Ondergewaardeerde aandelen. Indien de marktwaarde van de aandelen van een onderneming ondergewaardeerd is zullen, vanwege het onder ad. 5 gepresenteerde 'levered security' argument, warrants nog meer ondergewaardeerd zijn. In een dergelijk geval zal een emissie van gewone obligaties de voorkeur verdienen. Indien een onderneming, om welke reden dan ook, geen gewone obligaties uit wenst te geven, kan een emissie van converteerbare obligaties (of warrant-obligaties) uitkomst bieden. Opgemerkt wordt dat de warrant component in dit geval niet te groot mag zijn, aangezien in dat geval de emissie van aandelen te verkiezen zal zijn.

\section{Ad. 7 Accounting voordelen.}

Warrant-leningen kunnen in een aantal gevallen op een dusdanige manier in de boekhouding worden verwerkt dat de verlies- en winstrekening en de balans samen een hoger financieel hefboomeffect genereren. In een onderzoek constateren Duffhues en Veld (1991) dat een aantal Nederlandse ondernemingen warrant-leningen op een zodanige manier in de boekhouding verwerkt (door toepassing van de zogenaamde pari-methode) dat een hogere Rentabiliteit van het Eigen Vermogen (REV) wordt gepresenteerd dan het geval zou zijn geweest als de meer bij de economische ratio aansluitende 'methode van het gepassiveerd disagio' zou zijn toegepast. ${ }^{14}$ Deze hogere REV vindt zijn oorzaak in het feit dat bij de pari-methode een relatief lage interestlast in de verlies- en winstrekening wordt verwerkt en een relatief hoog bedrag aan vreemd vermogen in de balans. Dit leidt tot een relatief lage kostenvoet van het vreemd vermogen en bijgevolg tot een relatief hoge $\mathrm{REV} .^{15}$

Ad. 8 (Vermeende) fiscale voordelen.

In mei 1985 kondigde de staatssecretaris van $\mathrm{Fi}$ nanciën de zogenaamde 'warrant-resolutie' aan; deze werd geëffectueerd in februari 1986. De warrant-resolutie houdt in dat bij de emissie van een warrant-lening berekend wordt welk bedrag voor de warrants wordt betaald. Dit bedrag wordt bij de particuliere inschrijvers op de lening belast. ${ }^{16} \mathrm{De}$ mogelijkheid bestaat dat, met name vóór mei 1985 , ondernemingen gedacht hebben een voor particuliere beleggers fiscaal vriendelijke transactie gecreëerd te hebben. Dit zou dan tot mei 1985 een motief geweest kunnen zijn om warrant-leningen te emitteren. 
Ad. 9 De overwaardering van Nederlandse warrants. Veld (1992a $\left.{ }^{17}, 1992 b\right)$ constateert dat Nederlandse warrants zowel worden overgewaardeerd ten opzichte van langlopende call-opties als ten opzichte van buitenlandse warrants. ${ }^{18}$ Dit duidt erop dat voor Nederlandse warrants meer wordt betaald dan op grond van hun rendementsrisico verhouding zou mogen worden verwacht. Nederlandse ondernemingen zouden kunnen profiteren van deze overwaardering. Een interessante vraag is hoe de keuze tussen warrant-leningen en converteerbare obligatieleningen wordt gemaakt. Deze keuze wordt ook voornamelijk bepaald door markt-imperfecties, -inefficiënties en -incompleetheid. Voor een uitgebreide bespreking van deze vraag wordt verwezen naar het proefschrift en de daar aangehaalde literatuur. Een ander onderwerp dat uitgebreid is besproken in het proefschrift betreft de motieven om warrants, anders dan in combinatie met obligaties, uit te geven. Deze motieven kunnen voornamelijk worden afgeleid uit de motieven die in deze paragraaf zijn besproken.

\section{Motieven voor de uitgifte van warrant- leningen: resultaten van interviews met Neder- landse emittenten}

In mijn dissertatie is onderzocht in hoeverre de motieven, genoemd in paragraaf 3 , een rol hebben gespeeld bij de beslissingen van Nederlandse ondernemingen om warrant-leningen te emitteren. Daartoe is een gestandaardiseerde vragenlijst opgesteld voor de Nederlandse ondernemingen die warrant-leningen uit hebben gegeven. Functionarissen van deze ondernemingen zijn bezocht en hen is gevraagd om de vragenlijst in te vullen.

In tabel 1 wordt vermeld dat van 1976 tot en met 1991 in totaal 21 warrant-leningen zijn geëmitteerd. In tabel 2 wordt een overzicht gegeven van deze leningen.

In deze tabel kan worden afgelezen dat in totaal 18 verschillende ondernemingen betrokken zijn geweest bij de emissie van warrant-leningen. Van deze 18 ondernemingen hebben drie ondernemingen twee verschillende warrant-leningen uitgegeven, te weten KLM, Philips en Bredero Vastgoed. Ondanks het feit dat, door fusies, overnames en dergelijke, niet alle ondernemingen uit tabel 2 nog onder dezelfde naam bestaan, bleek het mogelijk om
Tabel 2: Emissies van warrant-leningen door Nederlandse ondernemingen op de nationale kapitaalmarkt

\begin{tabular}{|c|c|c|}
\hline \multirow{3}{*}{$\begin{array}{l}1976 \\
1977\end{array}$} & - & Nationale Nederlanden (US $\$ 30$ miljoen); \\
\hline & - & Naarden Internationaal ( $f$ 22,44 miljoen); \\
\hline & - & Westland Utrecht Hypotheekbank ( $f 33$ miljoen) \\
\hline \multirow[t]{5}{*}{1983} & & Ahold (f 100 miljoen); \\
\hline & - & Bredero Vastgoed ( $f 25$ miljoen): \\
\hline & - & KLM (f 100 miljoen); \\
\hline & & Philips (US \$200 miljoen): \\
\hline & - & VNU ( $f 60$ miljoen): \\
\hline \multirow[t]{2}{*}{1984} & & Bredero Vastgoed (f 30 miljoen); \\
\hline & - & Philips ( $f 300$ miljoen); \\
\hline \multirow[t]{2}{*}{1985} & & Bredero Verenigde Bedrijven (f 35 miljoen); \\
\hline & - & KLM (f 125 miljoen); \\
\hline \multirow[t]{2}{*}{1986} & & Bogamij (f 75 miljoen); \\
\hline & & Staal Bankiers (f 60 miljoen); \\
\hline \multirow[t]{4}{*}{1987} & - & Meneba ( $f$ 25,774 miljoen); \\
\hline & & Van Ommeren (f 75 miljoen); \\
\hline & - & Stork (f 100 miljoen): \\
\hline & - & KNP (f 175 miljoen). \\
\hline
\end{tabular}

voor alle ondernemingen, met uitzondering van Bredero Vastgoed en Bredero Verenigde Bedrijven, een functionaris te vinden die betrokken is geweest bij de beslissing om de desbetreffende warrant-lening te emitteren. Het uiteindelijke onderzoek bestond dan ook uit 16 interviews met functionarissen van 16 ondernemingen die in totaal 18 warrant-leningen uit hebben gegeven. In paragraaf 3 hebben we gezien dat sommige van de motieven om een warrant-lening uit te geven tijdgebonden (kunnen) zijn, dit geldt bijvoorbeeld voor de verwachtingen omtrent de fiscale behandeling van warrant-leningen of de (vermeende) over- of onderwaardering van het onderliggende aandeel. Besloten is daarom om voor alle warrant-leningen een aparte enquête op te nemen, hetgeen betekent dat in totaal 18 enquêteformulieren zijn verwerkt.

De gebruikte methodologie is er één die reeds vaker in de financieringsliteratuur is toegepast. ${ }^{19}$ Voor het interview is een lijst opgesteld met de motieven, zoals genoemd in paragraaf 3 . De respondenten is gevraagd om een score aan deze motieven toe te kennen op een schaal van $1 \mathrm{t} / \mathrm{m}$ 5, waarbij 1 staat voor onbelangrijk en 5 voor belangrijk. Na ontvangst van alle enquêtes is iedere score vermenigvuldigd met het percentage antwoorden binnen die klasse. Het resulterend gemiddelde vormt de score voor elk motief. ${ }^{20}$ Deze procedure is allereerst uitgevoerd voor de traditionele motieven. De resultaten hiervan zijn opgenomen in tabel 3. Uit deze tabel zien we dat 
Tabel 3: Relatief belang van de traditionele motieven voor de uitgifte van warrant-leningen door Nederlandse ondernemingen

\begin{tabular}{lllllll}
\hline Motief & 1 & 2 & 3 & 4 & 5 & gemiddelde
\end{tabular}

\begin{tabular}{|c|c|c|c|c|c|c|}
\hline $\begin{array}{l}1 \text { Goedkope vorm van } \\
\text { vreemd vermogen }\end{array}$ & $0 \%$ & $0 \%$ & $11 \%$ & $28 \%$ & $61 \%$ & 4,50 \\
\hline $\begin{array}{l}2 \text { Uitgestelde aan- } \\
\text { delen emissie tegen } \\
\text { een gunstige prijs }\end{array}$ & $11 \%$ & $6 \%$ & $22 \%$ & $22 \%$ & $39 \%$ & 3,72 \\
\hline
\end{tabular}

met name het argument dat een warrant-lening een goedkope vorm van vreemd vermogen is (nog steeds) heel populair is. Vrijwel alle respondenten gaven een score van 4 of 5 aan dit argument. Het argument van de 'uitgestelde aandelenemissie tegen een gunstige prijs' is minder populair; de gemiddelde score bedroeg slechts 3,72 tegenover een gemiddelde score voor het 'goedkoop vreemd vermogen argument' van 4,50. Volgens de respondenten is deze score lager dan de score voor het goedkoop vreemd vermogen argument, omdat het niet zeker is dat warrant-uitoefening daadwerkelijk plaats zal vinden.

Teneinde het belang van de traditionele motieven verder te onderzoeken, is aan de respondenten de volgende vraag gesteld:

Bent $u$ van mening dat $u$ door de warrant-lening goedkoop gefinancierd heeft? (goedkoop staat voor een lage gemiddelde vermogenskostenvoet (cost of capital))

Maar liefst $83 \%$ van de respondenten beantwoord de deze vraag met 'ja', $11 \%$ antwoordde met 'nee' en de overige $6 \%$ antwoordde met 'gemiddeld'. Uit deze antwoorden blijkt het grote verschil tussen theorie en praktijk. Ondanks de theoretische constatering dat warrant-leningen géén goedkope bronnen van vermogen zijn, blijkt dat in de praktijk warrant-leningen wèl als een goedkope vorm van vermogen worden beschouwd. In deze context is het interessant om op te merken dat één van de respondenten opmerkte dat hij op het moment van de emissie, de warrant-lening als een goedkope vorm van vermogen beschouwde, maar dat op grond van de hoge 'opportunity kosten', in de vorm van het verschil tussen de aandeelprijs op het moment van warrant-uitoefening en de warrant uitoefenprijs, hij de warrant-lening achteraf als een (heel) dure vorm van vermogen beschouwde.

In tabel 4 worden de resultaten voor de economisch rationele motieven gepresenteerd. Allereerst kan worden opgemerkt dat de scores voor de 'moderne' motieven (veel) lager zijn dan die voor de traditionele motieven. Het motief dat het 'beste' scoort is de overwaardering van Nederlandse warrants. Dit motief scoort vooral goed bij de warrant-leningen die sinds 1986 zijn geëmitteerd. Andere motieven, waarvan regelmatig wordt genoemd dat ze een rol hebben gespeeld bij de beslissing om een warrant-lening te emitteren, zijn: lagere transactiekosten, accounting voordelen en de relatieve ongevoeligheid van de warrant-lening ten opzichte van het (huidige) risico van de onderneming.

Opgemerkt kan worden dat in sommige gevallen overwaardering en in andere gevallen onderwaardering van de onderliggende aandelen een rol heeft

Tabel 4: Relatief belang van de 'moderne' motieven voor de uitgifte van warrant-leningen door Nederlandse ondernemingen

\begin{tabular}{|c|c|c|c|c|c|c|}
\hline Motief & 1 & 2 & 3 & 4 & 5 & gemiddelde \\
\hline $\begin{array}{l}1 \text { Overgewaardeerde } \\
\text { warrants }\end{array}$ & $44 \%$ & $6 \%$ & $11 \%$ & $17 \%$ & $22 \%$ & 2,67 \\
\hline $\begin{array}{l}2 \text { Ondergewaardeerde } \\
\text { aandelen }\end{array}$ & $50 \%$ & $11 \%$ & $11 \%$ & $6 \%$ & $22 \%$ & 2,39 \\
\hline $\begin{array}{l}3 \text { Lagere transactie- } \\
\text { kosten }\end{array}$ & $28 \%$ & $28 \%$ & $28 \%$ & $17 \%$ & $0 \%$ & 2,33 \\
\hline $\begin{array}{l}4 \text { Accounting voor- } \\
\text { delen }\end{array}$ & $44 \%$ & $22 \%$ & $22 \%$ & $0 \%$ & $11 \%$ & 2,11 \\
\hline $\begin{array}{l}5 \text { Relatieve ongevoe- } \\
\text { ligheid voor huidige } \\
\text { risico }\end{array}$ & $56 \%$ & $11 \%$ & $22 \%$ & $11 \%$ & $0 \%$ & 1,89 \\
\hline $\begin{array}{l}6 \text { Fiscale voordelen } \\
7 \text { Overgewaardeerde } \\
\text { aandelen } \\
8 \text { Vermindering van } \\
\text { agency kosten }\end{array}$ & $\begin{array}{l}78 \% \\
83 \%\end{array}$ & $\begin{array}{l}0 \% \\
6 \%\end{array}$ & $0 \%$ & $17 \%$ & $11 \%$ & 1,50 \\
\hline $\begin{array}{l}9 \text { Mogelijkheid om } \\
\text { liquiditeitspro- } \\
\text { blemen op te } \\
\text { lossen }\end{array}$ & $83 \%$ & $0 \%$ & $17 \%$ & $0 \%$ & $0 \%$ & 1,33 \\
\hline
\end{tabular}


gespeeld. Het motief dat de meeste aandacht krijgt in de theorie, de mogelijkheid om agency-kosten te vermijden, scoort zeer laag in de enquête. Dit duidt wederom op een verschil tussen theorie en praktijk. De lage score voor de mogelijkheid om liquiditeitsproblemen op te lossen, hangt samen met het feit dat de geïnterviewde ondernemingen meestal grote Nederlandse ondernemingen betreffen, terwijl het liquiditeitsmotief met name betrekking heeft op kleine snelgroeiende ondernemingen.

Conclusie van deze paragraaf is dat de meeste respondenten voornamelijk gedreven werden door de traditionele motieven. De moderne motieven bleken slechts een ondergeschikte rol te spelen.

\section{Conclusies en aandachtspunten voor toekom- stig onderzoek}

Aan de hand van mijn proefschrift (Veld, 1992a) is in dit artikel aandacht besteed aan motieven om warrants uit te geven. Aangezien warrants meestal worden geëmitteerd in combinatie met obligaties, heeft deze emissievorm centraal gestaan in dit artikel. Allereerst is aandacht besteed aan de motieven voor uitgifte van warrant-leningen, die kunnen worden verdeeld in traditionele en moderne motieven. Aangetoond is dat vanuit een doelstelling van marktwaardemaximalisatie de traditionele motieven als irrationeel kunnen worden beschouwd. Vanuit de genoemde doelstelling kunnen de moderne motieven, welke gebaseerd zijn op (markt) imperfecties, inefficiënties en incompleetheid, als meer economisch rationeel worden beschouwd. Het bleek mogelijk te zijn om voor Nederlandse ondernemingen die op de Nederlandse kapitaalmarkt warrant-leningen emitteren, een negental moderne motieven te vinden. Door middel van interviews met managers van de meeste Nederlandse ondernemingen die sinds 1976 warrant-leningen hebben geëmitteerd (op de Nederlandse kapitaalmarkt) is bezien door welke motieven deze ondernemingen zich hebben laten leiden. Uit deze interviews volgde de conclusie dat de ondernemingen zich voornamelijk hebben laten leiden door de traditionele motieven. De moderne motieven bleken slechts een ondergeschikte rol te spelen. Dit duidt op een afwijking tussen theorie en praktijk. Een mogelijke verklaring voor deze afwijking is de mogelijkheid dat managers, in tegenstelling tot de belangrijkste veronderstelling in de financieringstheorie, niet trachten om de marktwaarde van de onderneming te maximaliseren. Dit werd ook bevestigd in een recente studie van Cools (1991), die de financiële topmanagers van vijttig van de grootste Nederlandse ondernemingen heeft geïnterviewd. Uit deze interviews concludeerde hij dat slechts enkele managers marktwaarde-maximalisatie van het eigen vermogen als hun belangrijkste doel beschouwden. Eerder, in 1987, bekritiseerde Tempelaar deze veronderstelling vanuit een theoretisch standpunt. Het zoeken naar de werkelijke drijfveren van managers lijkt dan ook een interessant aandachtspunt voor toekomstig onderzoek.

Een ander mogelijk aandachtspunt betreft het grote aantal warrant-leningen dat door Japanse ondernemingen is geëmitteerd. Van 1983 tot 1989 hebben Japanse ondernemingen meer dan 1400 warrant-leningen geplaatst. Opvallend is dat slechts een klein gedeelte hiervan op de Japanse markt is uitgegeven; in plaats daarvan is het grootste gedeelte op de Eurobond markt geplaatst. In het proefschrift is een verkennende analyse gemaakt van deze Japanse warrant-leningen. Verder onderzoek naar de motieven om deze leningen uit te geven verdient zeker een plaats op de onderzoeksagenda.

\section{Literatuur}

Black, F. en Scholes. M.: 'The pricing of options and corporate liabilities'. Journal of Political Economy, 1973, blz. 637-654

Brealey, R.A. en Myers, S.C.: 'Principles of corporate finance', Mc. Graw-Hill Book Company, New York (VS). 1991.

Brennan. M.J. en Schwartz, E.S.: 'The case for convertibles'. Journal of Applied Corporate Finance. Summer 1988, blz. 55-64.

Cools. K.: 'Financiële topmanagers over hun vermogensstructuur'. Maandblad voor Accountancy en Bedrijfseconomie. 1991, blz. 87-101.

Copeland, T.E. en Weston, E.F.: 'Financial theory and corporate policy. Addison-Wesley. Reading (VS), 1988.

Cremers. F.J.M.G.: 'De rol van de warrant als financieringsvorm voor de onderneming'. NIBE/Kluwer publicatie no. 37. Deventer, 1979.

Duffhues, P.J.W.: 'Ontwikkelingen in het gebruik van warrants op de nationale en internationale kapitaalmarkten', in: 'Financiële Instrumenten (Moderne vormen van financiering en risicobeheersing)', P.J.W. Duffhues. J.G. Groeneveld, en J. van der Hilst (red.). Kluwer Bedrijfswetenschappen. Deventer. 1991. blz. 119-135. 
Duffhues, P.J.W. en Veld, C.H.: 'De verwerking van aandelenwarrants in het jaarrapport'. in: 'Jaar in -Jaar uit 5', J. Dijksma en C.D. Knoops (red.), Wolters Noordhoff, Groningen, 1991, blz. 139-160.

Economist (The): 'Japan's warrant hangover', The Economist, 8 september 1990, blz. 95-96.

Finnerty, J.D.: 'The case for issuing synthetic convertible bonds', Midland Corporate Finance Journal, Fall 1986, blz. 73-82.

Francis, A.: 'Company objectives, managerial motivations and the behaviour of large firms: an empirical test of the theory of 'managerial' capitalism', Cambridge Journal of Economics, 1980, blz. 349-361.

Geld, van der, J.A.G.: 'Fiscale aspecten van nieuwe financiële instrumenten', in: 'Financiële Instrumenten (Moderne vormen van financiering en risicobeheersing)', P.J.W. Duffhues, J.G. Groeneveld, en J. van der Hilst (red.), Kluwer Bedrijfswetenschappen, Deventer, 1991, blz. 203-222.

Ghosh, C., Varma, R. en Woolridge, J.R.: 'An analysis of exchangeable debt offers', Journal of Financial Economics, 1990, blz. 251-263.

Green, R.C.: 'Investment incentives, debt, and warrants', Journal of Financial Economics, 1984, blz. 115-136.

Haugen, R.A. en Senbet, L.W.: 'Resolving the agency problems of external capital through options', The Journal of Finance, 1981. blz. 629-647

Jensen, M.C. en Meckling, W.H.: 'Theory of the firm: managerial behavior, agency costs and ownership structure', Journal of Financial Economics, 1976 , blz. 305-360

Jones, E.P. en Mason, S.P.: 'Equity-linked debt', Midland Corporate Finance Journal, Winter 1986, blz. 47-58

Mikkelson, W.H. en Partch, M.M.: 'Valuation effects of security offerings and the issuance process', Journal of Financial Economics, 1986, blz. 31-60

Modigliani, F. en Miller, M.: 'The cost of capital, corporation finance, and the theory of investment'. American Economic Review, 1958, blz. 261-297.

Pinegar, J.M. en Wilbricht, L.: 'What managers think of capital structure theory: a survey', Financial Management, Winter 1989, blz. 82-91.

Tamminga. M.K. en Oudejans, T.T.: 'Converteerbare obligatie trekt zich niets aan van beursklimaat', Het Financieele Dagblad, 28 december 1991.

Tempelaar, F.M.: 'De financieringsfunctie van warrantleningen', Maandblad voor Accountancy en Bedrijfshuishoudkunde. 1986, blz. 258-271.

Tempelaar, F.M.: 'Vermogensmarkt en ondernemingsdoel in de financieringstheorie', Groningen, 1987.

veld, C.H.: 'Analysis of equity warrants as investment and finance instruments', Tilburg University Press, Tilburg, 1992a.

Veld, C.H.: 'De waardering van Nederlandse aandelenwarrants', publicatie in voorbereiding, $1992 \mathrm{~b}$

Veld, C.H. en Grazell, J.: 'Motieven voor de uitgifte van converteerbare obligatieleningen en warrantobligatie-leningen', Maandblad voor Bedrijfsadministratie en Bedrijfsorganisatie, 1991, blz. 2-7.

Veld, C.H. en Verboven, A.H.F.: 'Anomalies in the pricing of war- rants versus the pricing of long term call-options'. Paper gepresenteerd op het 19e congres van de European Finance Association, Lissabon, augustus 1992.

\section{Noten}

1 De auteur dankt prof. dr. P.W. Moerland, prof. dr. F.M. Tempelaar en drs. A.B.P.G. Schmeits voor hun kritische opmerkingen bij een eerdere versie van dit artikel.

2 Zie ook Duffhues (1991).

3 Zie ook Duffhues (1991).

4 Inclusief ondernemingen gevestigd op de Nederlandse Antillen. 5 In mei en juni 1992 hebben warrant-emissies plaatsgevonden door respectievelijk Econosto en Philips. Deze brengen het totaal aan emissies sinds 1976 op 45, en het totale aantal uitgegeven verschillende warrants op 51.

6 Claimrechten zijn uiteraard niet opgenomen in tabel 1.

7 Deze traditionele motieven worden voornamelijk genoemd in de niet-academische literatuur, zie bijvoorbeeld een artikel in The Economist van 8 september 1990 , of meer recent een artikel van Tamminga en Oudejans in Het Financieele Dagblad van 28 december 1991. Echter, zelfs in de academische literatuur zijn deze motieven (nog) niet helemaal verdwenen; zie bijvoorbeeld Ghosh, Varma en Woolridge (1990).

8 Voor een meer uitgebreide bespreking zie hoofdstuk 5 en 6 van mijn proefschrift.

9 Zie Black en Scholes (1973).

10 Met betrekking tot dit zogenaamde 'risk-shifting' (risicoverschuivings) probleem schrijven Jensen en Meckling (1976) zelf dat het twijfelachtig is dat de waarde van het totale vermogen constant zal blijven. Dit is de reden dat Green (1984) het 'risk-shifting' probleem expliciet heeft gemodelleerd. Hij kwam hierbij evenwel tot de conclusie dat het 'risk-shifting' probleem inderdaad bestaat.

11 Zie ook Haugen en Senbet (1981).

12 Bijvoorbeeld vanwege een heersende informatie-asymmetrie. 13 Zie Jones en Mason (1986).

14 Deze laatste methode wordt overigens in de Verenigde Staten voorgeschreven bij het verwerken van warrant-leningen in de jaarrekening; zie Finnerty (1986).

15 Aangezien een relatief hoog bedrag aan vreemd vermogen in de balans wordt verwerkt leidt de pari-methode tot een zwakkere vermogensstructuur, hetgeen een optisch nadeel is voor de betreffende onderneming.

16 Voor een uitgebreide bespreking van de fiscale aspecten verbonden aan warrant-leningen, zie o.a. Tempelaar (1986) en Van der Geld (1991).

17 Zie met name hoofdstuk 3 en 4.

18 Voor de bespreking van de waarderingsverschillen tussen warrants en langlopende call-opties, zie ook Veld en Verboven (1992).

19 Zie bijvoorbeeld Francis (1980) en Pinegar en Wilbricht (1989).

20 Zie bijvoorbeeld motief 1 in tabel 3 (goedkoop vreemd vermogen). Het gemiddelde is berekend als: $0,11^{*} 3+0,28^{*} 4+0,61^{\star} 5$ $=4,50$. 